Article

\title{
Bioactive Cembranoids from the South China Sea Soft Coral Sarcophyton elegans
}

\author{
Xin Liu ${ }^{1}$, Junsheng Zhang ${ }^{1}$, Qiao Liu ${ }^{1}$, Guihua Tang ${ }^{1}$, Hongsheng Wang ${ }^{1}$, Chengqi Fan ${ }^{2}$ \\ and Sheng Yin $1, *$
}

1 School of Pharmaceutical Sciences, Sun Yat-sen University, Guangzhou 510006, China; E-Mails: liux66@mail2.sysu.edu.cn (X.L.) zhangjsh0814@163.com (J.Z.); 15521123303@163.com (Q.L.); tanggh5@mail.sysu.edu.cn (G.T.); whongsh@mail.sysu.edu.cn (H.W.)

2 East China Sea Fisheries Research Institute, Chinese Academy of Fishery Sciences, Shanghai 200090, China; E-Mail: chengqifan92@pku.org.cn

* Author to whom correspondence should be addressed; E-Mail: yinsh2@mail.sysu.edu.cn; Tel./Fax: +86-20-3994-3090.

Academic Editor: John Beutler

Received: 13 June 2015 / Accepted: 13 July 2015 / Published: 22 July 2015

\begin{abstract}
Four new cembranoids, sarcophelegans A-D (1-4) and six known analogues (5-10) were isolated from the South China Sea soft coral Sarcophyton elegans. Their structures were elucidated through detailed spectroscopic analysis, and the absolute configuration of 1 was confirmed by single-crystal X-ray diffraction. The antimigratory potential of compounds 1-10 were evaluated and compounds $\mathbf{2}$ and $\mathbf{6}$ were found to inhibit human breast tumor MDA-MB-231 cell migration at $10 \mu \mathrm{M}$.
\end{abstract}

Keywords: Sarcophyton elegans; cembranoids; antimigratory activity

\section{Introduction}

Cembranoids are a group of highly functionalized dierpenoids with a 14-membered carbon ring, an isopropyl residue, and three methyls [1]. Since the first representative, cembrene, was isolated from the pine tree Pinus albicaulis Engelm in 1962, hundreds of cembranoids have been reported from plants, insects, alligators, and especially from marine organisms [1,2]. Although cembranoids are indisputably 
not uniquely marine, their striking presence in soft corals, especially in the genus Sarcophyton (Alcyoniidae) $[3,4]$, outstrips their occasional occurrence in other taxa. In recent years, the significant biological activity of cembranoids in terms of antimicrobial, anti-cancer and anti-inflammation effects, together with their fascinating architectures, have attracted great interest from natural product $[5,6]$ and pharmaceutical chemists $[7,8]$.

The soft coral species of the genus Sarcophyton are widely distributed along tropic and subtropic oceans. So far, around 30 species of this genus from different locations have been chemically examined [9]. Previous chemical investigations of $S$. elegans have led to the isolation of several cembranoids, tetracyclic diterpenoids, steroids, and carotenoids [9-16]. As part of our continuing efforts to discover structurally intriguing and bioactivity-significant metabolites from South China Sea marine invertebrates [17-19], we undertook a detailed chemical analysis of S. elegans, collected in the Xisha Islands, South China Sea, which led to the isolation of four new cembranoids (1-4) and six known compounds (5-10) (Figure 1). The antimigratory potential of compounds $\mathbf{1 - 1 0}$ was evaluated and compounds $\mathbf{2}$ and $\mathbf{6}$ were found to inhibit human breast tumor MDA-MB-231 cell migration at $10 \mu \mathrm{M}$. Herein, details of the isolation, structure elucidation, and antimigratory activity of these compounds are described.

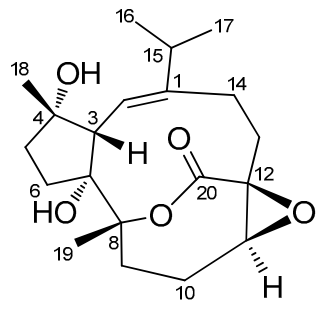

1

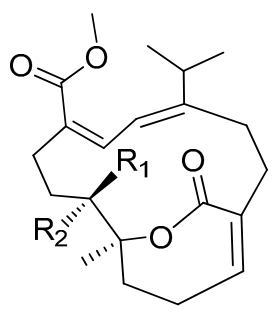

$5 \quad \mathrm{R}_{1}=\mathrm{OAC} \quad \mathrm{R}_{2}=\mathrm{H}$

$6 \quad \mathrm{R}_{1}=\mathrm{O} \quad \mathrm{R}_{2}=\mathrm{O}$

$\begin{array}{lll}7 & \mathrm{R}_{1}=\mathrm{H} & \mathrm{R}_{2}=\mathrm{OAC}\end{array}$

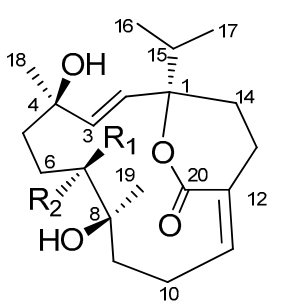

$2 \mathrm{R}_{1}=\mathrm{O} \quad \mathrm{R}_{2}=\mathrm{O}$

$3 \mathrm{R}_{1}=\mathrm{OH} \mathrm{R}_{2}=\mathrm{H}$

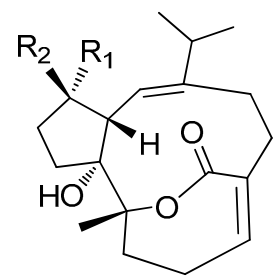

$8 \mathrm{R}_{1}=\mathrm{OH} \quad \mathrm{R}_{2}=\mathrm{CH}_{3}$

$9 \quad \mathrm{R}_{1}=\mathrm{CH}_{3} \quad \mathrm{R}_{2}=\mathrm{OH}$

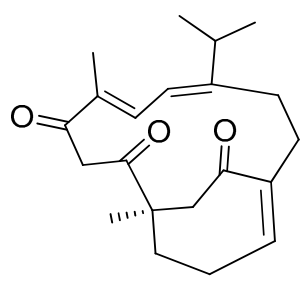

4

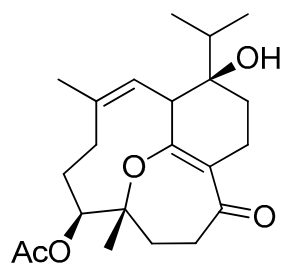

10

Figure 1. Compounds 1-10 isolated from Sarcophyton elegans.

\section{Results and Discussion}

\subsection{Structural Elucidation of New Compounds}

The soft coral of $S$. elegans ( $1 \mathrm{~kg}$, wet weight) was freeze-dried, ground, and extracted with a mixture of $\mathrm{CH}_{2} \mathrm{Cl}_{2} / \mathrm{MeOH}(v / v, 1: 1)$ at room temperature. After removal of solvent in vacuo, the residue was suspended in $\mathrm{H}_{2} \mathrm{O}$ and then partitioned sequentially with petroleum ether (PE) and EtOAc. Various column chromatographic separations of the EtOAc extract afforded compounds 1-10.

Compound 1, a colorless crystal, had the molecular formula $\mathrm{C}_{20} \mathrm{H}_{30} \mathrm{O}_{5}$, as determined by HRESIMS at $m / z 333.2059\left[\mathrm{M}-\mathrm{H}_{2} \mathrm{O}+\mathrm{H}\right]^{+}($calcd 333.2066), corresponding to six degrees of unsaturation. The IR 
spectrum exhibited absorption bands for hydroxyl $\left(3451 \mathrm{~cm}^{-1}\right)$ and carbonyl $\left(1716 \mathrm{~cm}^{-1}\right)$ functionalities The ${ }^{1} \mathrm{H}-\mathrm{NMR}$ data (Table 1$)$ of 1 showed two methyl singlets $\left[\delta_{\mathrm{H}} 1.10\left(3 \mathrm{H}, \mathrm{s}, \mathrm{CH}_{3}-18\right)\right.$ and $1.34(3 \mathrm{H}, \mathrm{s}$, $\left.\left.\mathrm{CH}_{3}-19\right)\right]$, an isopropyl group [ $\delta_{\mathrm{H}} 1.09\left(3 \mathrm{H}, \mathrm{d}, J=6.9 \mathrm{~Hz}, \mathrm{CH}_{3}-17\right), 1.19\left(3 \mathrm{H}, \mathrm{d}, J=6.9 \mathrm{~Hz}, \mathrm{CH}_{3}-16\right)$, and $2.34(1 \mathrm{H}, \mathrm{m}, \mathrm{H}-15)]$, an oxygenated methine $\left[\delta_{\mathrm{H}} 3.13(1 \mathrm{H}, \mathrm{dd}, J=7.0,7.0 \mathrm{~Hz}, \mathrm{H}-11)\right]$, an olefinic proton $[\delta \mathrm{H} 5.69(1 \mathrm{H}, \mathrm{d}, J=11.3 \mathrm{~Hz}, \mathrm{H}-2)]$, and a series of aliphatic methylene multiplets. The ${ }^{13} \mathrm{C}-\mathrm{NMR}$ data (Table 2), in combination with DEPT experiments, resolved 20 carbon resonances attributable to an ester carbonyl group $\left(\delta_{\mathrm{C}} 173.9\right)$, a trisubstituted double bond $\left(\delta_{\mathrm{C}} 120.1,147.1\right)$, four $\mathrm{sp}^{3}$ oxygenated quaternary carbons, three $\mathrm{sp}^{3}$ methines (one oxygenated), six $\mathrm{sp}^{3}$ methylenes, and four methyls. The above-mentioned data implied that 1 possessed most of the structural features of cembranoid diterpenes, which showed high similarity to those of co-isolated sarsolilide B (8) [20]. In comparison with $\mathbf{8}$, the signals for $\Delta^{11}$ in 8 were replaced by the signals for an epoxy in $\mathbf{1}\left[\delta_{\mathrm{H}} 3.13(1 \mathrm{H}, \mathrm{dd} J=7.0,7.0 \mathrm{~Hz})\right.$; $\delta_{\mathrm{C}} 65.6(\mathrm{CH})$ and $60.4(\mathrm{C})$ ], indicating that 1 was an 11,12-epoxy derivative of $\mathbf{8}$. This was confirmed by HMBC correlations from both $\mathrm{H}-10$ and $\mathrm{H}-13$ to $\mathrm{C}-11$ and $\mathrm{C}-12$, as well as the downfield-shifted carbonyl at C-20 ( $\delta_{\mathrm{C}} 173.9$ in $\mathbf{1} ; \delta_{\mathrm{C}} 170.3$ in $\mathbf{8}$ ) (Figure 2 ). The relative configuration of $\mathbf{1}$ was assigned to be the same as that of $\mathbf{8}$ by comparing their 1D NMR and NOESY data. In particular, the NOESY correlation between H-11 and H-13a indicated the epoxy ring was cis-oriented (Figure S6). Finally, the successful performance of the X-ray crystallographic analysis using anomalous scattering of $\mathrm{Cu} \mathrm{K} \alpha$ radiation verified the proposed structure and also allowed unambiguous assignment of the absolute configuration of $\mathbf{1}$ as drawn in Figure 3. Thus, compound $\mathbf{1}$ was determined as depicted and given the trivial name sarcophelegan A.

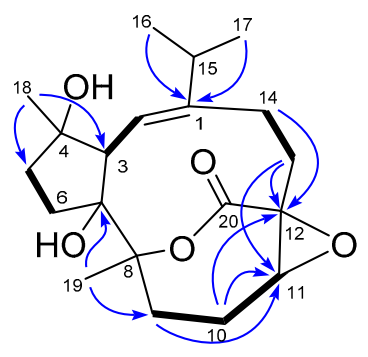

1

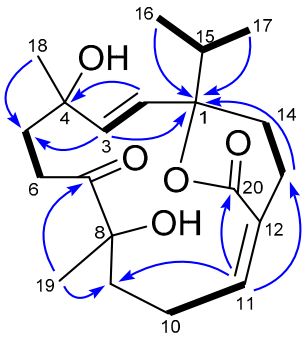

2

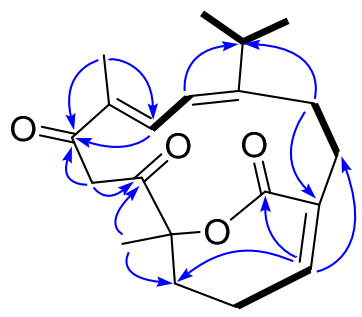

4

Figure 2. $\operatorname{Key}{ }^{1} \mathrm{H}-{ }^{1} \mathrm{H} \operatorname{COSY}(-)$ and $\operatorname{HMBC}(\rightarrow)$ correlations for $\mathbf{1}, \mathbf{2}$, and 4 .

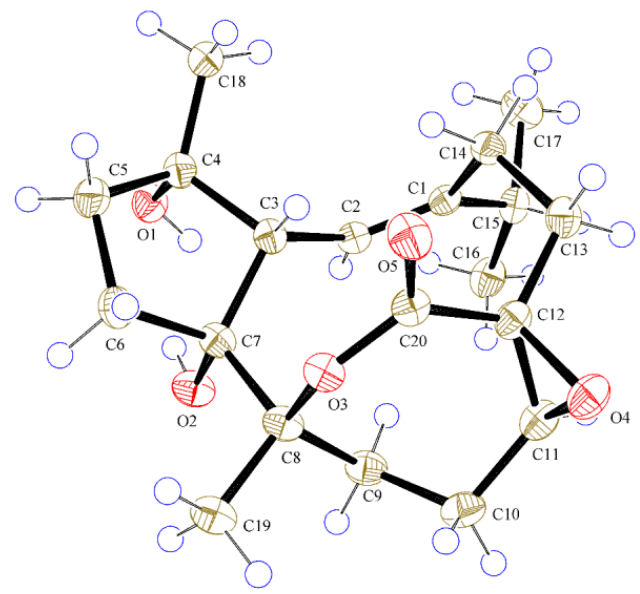

Figure 3. ORTEP depiction for X-ray crystal structures of $\mathbf{1}$. 
Table 1. ${ }^{1} \mathrm{H}-\mathrm{NMR}$ spectroscopic data of $\mathbf{1}-\mathbf{4}(400 \mathrm{MHz}, J$ in $\mathrm{Hz}, \delta$ in ppm).

\begin{tabular}{ccccc}
\hline Position & $\mathbf{1}^{\mathbf{a}}$ & $\mathbf{2}^{\mathrm{a}}$ & $\mathbf{3}^{\mathrm{a}}$ & $\mathbf{4}^{\mathbf{b}}$ \\
\hline 2 & $5.69, \mathrm{~d}(11.3)$ & $5.55, \mathrm{~d}(16.7)$ & $5.54, \mathrm{~d}(16.3)$ & $6.23 \mathrm{~d}(11.4)$ \\
3 & $2.35, \mathrm{~m}$ (overlapped) & $5.69, \mathrm{~d}(16.7)$ & $5.74, \mathrm{~d}(16.3)$ & $6.72, \mathrm{brd}(11.4)$ \\
$5 \mathrm{a}$ & $1.98, \mathrm{~m}$ & $1.77, \mathrm{~m}$ (overlapped) & $1.83, \mathrm{~m}$ (overlapped) & \\
$5 \mathrm{~b}$ & $1.87, \mathrm{~m}$ & $1.55, \mathrm{ddd}(14.2,10.5,7.4)$ & $1.46, \mathrm{~m}$ & \\
$6 \mathrm{a}$ & $2.21, \mathrm{~m}$ & $3.04, \mathrm{ddd}(20.9,10.5,7.4)$ & $1.70, \mathrm{~m}$ & $4.90, \mathrm{~d}(16.8)$ \\
$6 \mathrm{~b}$ & $1.90, \mathrm{~m}$ & $2.44, \mathrm{~m}$ (overlapped) & $1.38, \mathrm{~m}$ & $3.29, \mathrm{~d}(16.8)$ \\
7 & & & $3.25, \mathrm{brd}(11.0,1.4)$ & \\
$9 \mathrm{a}$ & $2.82, \mathrm{dd}(14.4,14.4)$ & $1.96, \mathrm{~m}$ & $1.88, \mathrm{~m}$ & $2.40, \mathrm{~m}$ (overlapped) \\
$9 \mathrm{~b}$ & $1.73, \mathrm{dd}(14.4,7.6)$ & $1.77, \mathrm{~m}$ (overlapped) & $1.79, \mathrm{~m}$ & $2.01, \mathrm{~m}$ \\
$10 \mathrm{a}$ & $2.31, \mathrm{~m}$ & $3.40, \mathrm{~m}$ & $3.44, \mathrm{~m}$ & $2.73, \mathrm{~m}$ \\
$10 \mathrm{~b}$ & $1.38, \mathrm{~m}$ & $2.17, \mathrm{~m}$ & $2.05, \mathrm{~m}$ & $2.31, \mathrm{~m}$ \\
11 & $3.13, \mathrm{dd}(7.0,7.0)$ & $5.67, \mathrm{~m}$ & $6.19, \mathrm{dd}(10.1,5.1)$ & $6.10, \mathrm{dd}(4.1,4.1)$ \\
$13 \mathrm{a}$ & $2.62, \mathrm{~m}$ & $2.45, \mathrm{~m}($ overlapped) & $2.60, \mathrm{~m}$ & $3.19, \mathrm{~m}$ \\
$13 \mathrm{~b}$ & $1.30, \mathrm{~m}$ & & $2.55, \mathrm{~m}$ & $1.92, \mathrm{~m}$ \\
$14 \mathrm{a}$ & $2.51, \mathrm{~m}$ & $2.12, \mathrm{~m}$ & $2.16, \mathrm{~m}$ & $2.56, \mathrm{dd}(13.8,13.8)$ \\
$14 \mathrm{~b}$ & $2.12, \mathrm{~m}$ & $1.76 \mathrm{~m}$ & $1.84, \mathrm{~m}($ overlapped $)$ & $2.23, \mathrm{dd}(13.8,7.8)$ \\
15 & $2.34, \mathrm{~m}($ overlapped) & $1.86, \mathrm{~m}$ & $1.87, \mathrm{~m}$ & $2.41, \mathrm{~m}$ (overlapped) \\
16 & $1.19, \mathrm{~d}(6.9)$ & $0.98, \mathrm{~d}(6.8)$ & $0.98, \mathrm{~d}(7.1)$ & $1.07, \mathrm{~d}(6.8)$ \\
17 & $1.09, \mathrm{~d}(6.9)$ & $0.95, \mathrm{~d}(6.8)$ & $0.96, \mathrm{~d}(7.1)$ & $1.09, \mathrm{~d}(6.8)$ \\
18 & $1.10, \mathrm{~s}$ & $1.39, \mathrm{~s}$ & $1.33, \mathrm{~s}$ & $1.83, \mathrm{~s}$ \\
19 & $1.34, \mathrm{~s}$ & $1.21, \mathrm{~s}$ & $1.15, \mathrm{~s}$ & $1.54, \mathrm{~s}$ \\
\hline
\end{tabular}

${ }^{\mathrm{a}}$ Measured in $\mathrm{CD}_{3} \mathrm{OD} ;{ }^{\mathrm{b}}$ Measured in $\mathrm{CDCl}_{3}$.

Table 2. ${ }^{13} \mathrm{C}-\mathrm{NMR}$ spectroscopic data of $\mathbf{1}-\mathbf{4}(100 \mathrm{MHz}, \delta$ in ppm).

\begin{tabular}{|c|c|c|c|c|}
\hline Position & $1^{\mathrm{a}}$ & $2^{a}$ & $3^{\mathrm{a}}$ & $4^{b}$ \\
\hline 1 & $147.1, \mathrm{C}$ & $87.8, \mathrm{C}$ & $88.0, \mathrm{C}$ & $158.8, \mathrm{C}$ \\
\hline 2 & $120.1, \mathrm{CH}$ & $128.2, \mathrm{CH}$ & $128.3, \mathrm{CH}$ & $119.4, \mathrm{CH}$ \\
\hline 3 & $52.0, \mathrm{CH}$ & $140.4, \mathrm{CH}$ & $140.8, \mathrm{CH}$ & $137.8, \mathrm{CH}$ \\
\hline 4 & $83.4, \mathrm{C}$ & $72.8, \mathrm{C}$ & $73.4, \mathrm{C}$ & $133.3, \mathrm{C}$ \\
\hline 5 & $38.5, \mathrm{CH}_{2}$ & $36.5, \mathrm{CH}_{2}$ & $41.0, \mathrm{CH}_{2}$ & 195.1, C \\
\hline 6 & $34.7, \mathrm{CH}_{2}$ & $35.2, \mathrm{CH}_{2}$ & $25.4, \mathrm{CH}_{2}$ & $45.7, \mathrm{CH}_{2}$ \\
\hline 7 & $88.9, \mathrm{C}$ & 219.3, C & 76.0, $\mathrm{CH}$ & $204.3, \mathrm{C}$ \\
\hline 8 & $91.9, \mathrm{C}$ & 79.7, C & $75.8, \mathrm{C}$ & $86.1, \mathrm{C}$ \\
\hline 9 & $29.9, \mathrm{CH}_{2}$ & $42.0, \mathrm{CH}_{2}$ & $39.0, \mathrm{CH}_{2}$ & $33.3, \mathrm{CH}_{2}$ \\
\hline 10 & $24,1, \mathrm{CH}_{2}$ & 25.9, $\mathrm{CH}_{2}$ & $25.5, \mathrm{CH}_{2}$ & 27.2, $\mathrm{CH}_{2}$ \\
\hline 11 & $65.6, \mathrm{CH}$ & $150.3, \mathrm{CH}$ & $149.5, \mathrm{CH}$ & $143.6, \mathrm{CH}$ \\
\hline 12 & $60.4, \mathrm{C}$ & $125.1, \mathrm{C}$ & $125.5, \mathrm{C}$ & $130.9, \mathrm{C}$ \\
\hline 13 & $33.0, \mathrm{CH}_{2}$ & $25.0, \mathrm{CH}_{2}$ & $25.8, \mathrm{CH}_{2}$ & $37.1, \mathrm{CH}_{2}$ \\
\hline 14 & $25.8, \mathrm{CH}_{2}$ & $27.5, \mathrm{CH}_{2}$ & $27.5, \mathrm{CH}_{2}$ & 27.6, $\mathrm{CH}_{2}$ \\
\hline 15 & $34.0, \mathrm{CH}$ & $38.4, \mathrm{CH}$ & $38.9, \mathrm{CH}$ & $36.3, \mathrm{CH}$ \\
\hline 16 & 21.3, $\mathrm{CH}_{3}$ & 17.4, $\mathrm{CH}_{3}$ & $17.4, \mathrm{CH}_{3}$ & $22.4, \mathrm{CH}_{3}$ \\
\hline 17 & $23.9, \mathrm{CH}_{3}$ & $17.1, \mathrm{CH}_{3}$ & $17.1, \mathrm{CH}_{3}$ & 21.7, $\mathrm{CH}_{3}$ \\
\hline 18 & 26.2, $\mathrm{CH}_{3}$ & 29.3, $\mathrm{CH}_{3}$ & $30.2, \mathrm{CH}_{3}$ & $10.9, \mathrm{CH}_{3}$ \\
\hline 19 & $25.1, \mathrm{CH}_{3}$ & $28.5, \mathrm{CH}_{3}$ & $24.4, \mathrm{CH}_{3}$ & $28.9, \mathrm{CH}_{3}$ \\
\hline 20 & $173.9, \mathrm{C}$ & $168.8, \mathrm{C}$ & $169.5, \mathrm{C}$ & $165.8, \mathrm{C}$ \\
\hline
\end{tabular}

${ }^{\mathrm{a}}$ Measured in $\mathrm{CD}_{3} \mathrm{OD} ;{ }^{\mathrm{b}}$ Measured in $\mathrm{CDCl}_{3}$. 
Compound 2 possessed a molecular formula of $\mathrm{C}_{20} \mathrm{H}_{30} \mathrm{O}_{5}$ as determined by HRESIMS at $m / z 373.1986$ $[\mathrm{M}+\mathrm{Na}]^{+}$, which was compatible with its $1 \mathrm{D}$ NMR data. The ${ }^{1} \mathrm{H}-\mathrm{NMR}$ data of $\mathbf{2}$ (Table 1) showed signals for two methyl singlets $\left[\delta_{\mathrm{H}} 1.21,\left(3 \mathrm{H}, \mathrm{s}, \mathrm{CH}_{3}-19\right)\right.$ and $\left.1.39\left(3 \mathrm{H}, \mathrm{s}, \mathrm{CH}_{3}-18\right)\right]$, an isopropyl group [ $\delta_{\mathrm{H}} 0.95$ $\left(3 \mathrm{H}, \mathrm{d}, J=6.8 \mathrm{~Hz}, \mathrm{CH}_{3}-17\right), 0.98\left(3 \mathrm{H}, \mathrm{d}, J=6.8 \mathrm{~Hz}, \mathrm{CH}_{3}-16\right)$, and $\left.1.86(1 \mathrm{H}, \mathrm{m}, \mathrm{H}-15)\right]$, two trans-olefinic protons $\left[\delta_{\mathrm{H}} 5.55(1 \mathrm{H}, \mathrm{d}, J=16.7 \mathrm{~Hz}, \mathrm{H}-2)\right.$ and $\left.5.69(1 \mathrm{H}, \mathrm{d}, J=16.7 \mathrm{~Hz}, \mathrm{H}-3)\right]$, an olefinic proton [ $\delta_{\mathrm{H}} 5.67$ $(1 \mathrm{H}, \mathrm{m}, \mathrm{H}-11)]$, and a series of aliphatic methylene multiplets. The 20 carbon resonances were classified by DEPT experiments as a ketone carbonyl group ( $\left.\delta_{\mathrm{C}} 219.3\right)$, an ester carbonyl group $\left(\delta_{\mathrm{C}} 168.8\right)$, two double bonds ( $\delta_{\mathrm{c}} 125.1,128.2,140.4$, and 150.3 ), three $\mathrm{sp}^{3}$ oxygenated quaternary carbons, a sp $\mathrm{s}^{3}$ methine, six sp ${ }^{3}$ methylenes, and four methyls (Figure S8). The above-mentioned information was similar to that of sartrolide E [21]. However, analysis of HSQC and HMBC data (Figures S10 and S11) revealed that the chemical shift of $\mathrm{C}-1\left(\delta_{\mathrm{C}} 76.7\right)$ in sartrolide $\mathrm{E}$ was downfield-shifted to $\delta_{\mathrm{C}} 87.8$ in 2 , while $\mathrm{C}-8$ was upfield-shifted from $\delta_{C} 87.0$ to $\delta_{C} 79.7$ (Figure 2), indicating that the linkage of the lactone ring from C-12 to $\mathrm{C}-8$ in sartrolide $\mathrm{E}$ was migrated to $\mathrm{C}-1$ in 2 . This was further supported by comparison of the C-1 and C-8 chemical shifts of 2 with those of a known analogue, laevigatlactone E [22], sharing the similar lactone linkage as that in $\mathbf{2}\left(\delta_{\mathrm{C}} 87.9, \mathrm{C}-1\right.$ and $\delta_{\mathrm{C}} 73.2, \mathrm{C}-8$, in laevigatlactone $\left.\mathrm{E}\right)$.

The relative configuration of $\mathbf{2}$ was determined on the basis of the NOESY experiment (Figure S12). The NOESY correlation observed between $\mathrm{H}-11$ and $\mathrm{H}-13$ suggested the $E$ geometry for the $\Delta^{11}$. The crucial NOE correlations between $\mathrm{H}-2 / \mathrm{CH}_{3}-16$ and $\mathrm{H}-2 / \mathrm{CH}_{3}-18$ revealed that the isopropyl group and $\mathrm{CH}_{3}-18$ were co-facial and were arbitrarily designated as $\alpha$-oriented, while the interactions of $\mathrm{H}-5 \mathrm{a}$ with CH3-18 and $\mathrm{CH}_{3}-19$ indicated that the $\mathrm{CH}_{3}-18$ and $\mathrm{CH}_{3}-19$ were both $\alpha$-oriented (Figure 4). Thus, compound $\mathbf{2}$ was deduced as shown and named sarcophelegan B.

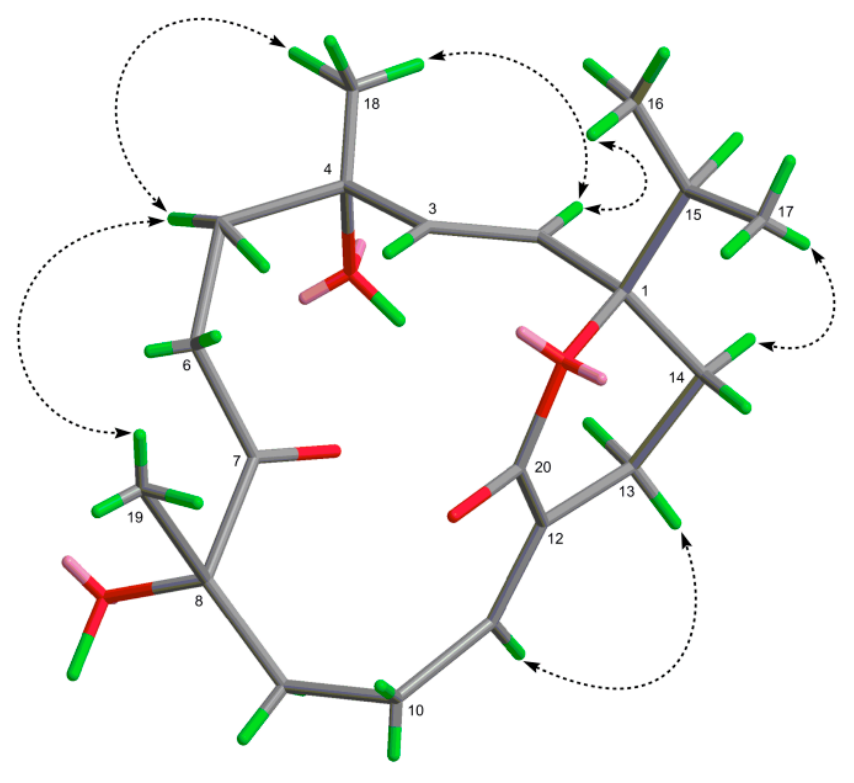

Figure 4. Selected NOESY correlations of $2(\leftrightarrow)$.

Compound 3 displayed the HRESIMS ion at $m / z$ 375.2147 $[\mathrm{M}+\mathrm{Na}]^{+}$, consistent with a molecular formula of $\mathrm{C}_{20} \mathrm{H}_{32} \mathrm{O}$, two mass units more than that of $\mathbf{2}$. The ${ }^{1} \mathrm{H}$ and ${ }^{13} \mathrm{C}$ NMR data of $\mathbf{3}$ (Tables 1 and 2) were very similar to those of 2 except for the presence of an additional oxygenated methine $\left(\delta \mathrm{H} 3.25 ; \delta_{\mathrm{C}}\right.$ 76.0 ) in $\mathbf{3}$ instead of the ketone group ( $\delta \mathrm{C} 219.3, \mathrm{C}-7)$ in $\mathbf{2}$, indicating that $\mathbf{3}$ was a 7-hydrogenated derivative of 2. HMBC correlation from $\mathrm{CH}_{3}-19$ and $\mathrm{H}_{2}-5$ to the oxygenated methine $\left(\delta_{\mathrm{C}} 76.0\right)$ confirmed 
the location of the hydroxyl group at $\mathrm{C}-7$. This was also supported by the upfield-shifted signals of C-6 and $\mathrm{C}-8$ in 3 with respect to those in 2 ( $\delta \mathrm{c} 25.4, \mathrm{C}-6 ; 75.8, \mathrm{C}-8$ in $\mathbf{3} ; \delta_{\mathrm{c}} 35.2, \mathrm{C}-6 ; 79.7, \mathrm{C}-8$ in 2 ). The relative configurations at $\mathrm{C}-1, \mathrm{C}-4$, and $\mathrm{C}-8$ of $\mathbf{3}$ were assigned to be the same as those of 2 by comparing their 1D NMR and NOESY data. The 7-OH was designated as $\beta$ by the NOE correlation between H-7 and $\mathrm{CH}_{3}-19$, as in the Chem3D molecular modeling study, the $7 \beta-\mathrm{OH}$ isomer of $\mathbf{3}$ display a distance of $2.573 \AA$ between $\mathrm{H}-7$ and $\mathrm{CH}_{3}-19$, while the $7 \alpha-\mathrm{OH}$ isomer showed a large distance of $3.738 \AA$ (Figure S25). Thus, compound $\mathbf{3}$ was deduced as shown and named sarcophelegan $\mathrm{C}$.

Compound 4, a colorless oil, exhibited a molecular formula of $\mathrm{C}_{20} \mathrm{H}_{26} \mathrm{O}_{4}$ as determined by HRESIMS and the data of ${ }^{13} \mathrm{C}-\mathrm{NMR}$. The ${ }^{1} \mathrm{H}$ - and ${ }^{13} \mathrm{C}$-NMR spectra of 4 (Figures S19 and S20) showed signals for two ketone signals ( $\delta_{\mathrm{C}} 195.1$ and 204.3), an $\alpha, \beta$-unsaturated- $\varepsilon$-lactone ( $\delta_{\mathrm{C}} 86.1,130.9,143.6$, and 165.8), an isopropyl group [ $\delta_{\mathrm{C}} 21.7,22.4$, and $36.3 ; \delta_{\mathrm{H}} 1.07(3 \mathrm{H}, \mathrm{d}, J=6.8 \mathrm{~Hz}, 1.09(3 \mathrm{H}, \mathrm{d}, J=6.8 \mathrm{~Hz})$ ), and 2.41 $(1 \mathrm{H}, \mathrm{m})$ ], two double bonds [ $\delta_{\mathrm{C}} 119.4,133.3,137.8$, and $158.8 ; \delta_{\mathrm{H}} 6.23(1 \mathrm{H}, \mathrm{d}, J=11.4 \mathrm{~Hz})$ and 6.72 $(1 \mathrm{H}, \mathrm{brd}, J=11.4 \mathrm{~Hz})]$, and two methyl singlets [ $\delta_{\mathrm{C}} 10.9$ and $28.9 ; \delta_{\mathrm{H}} 1.54(3 \mathrm{H}, \mathrm{s})$ and1.83 $\left.(3 \mathrm{H}, \mathrm{s})\right]$. These data showed high similarity to those of $(1 Z, 5 S, 9 E, 11 E)$-5,9-dimethyl-12-isopropyl-6-oxocyclotetradeca1,9,11-triene-1,5-carbolactone [23], a cembranoid diterpene previously reported from the same genus, except for the presence of an additional carbonyl group $\left(\delta_{\mathrm{C}} 195.1\right)$, which indicated that 4 was a carbonylated derivative of $(1 Z, 5 S, 9 E, 11 E)$-5,9-dimethyl-12-isopropyl-6-oxocyclotetradeca-1,9,11-triene1,5-carbolactone. $\mathrm{HMBC}$ correlations from $\mathrm{CH}_{3}-18$ and $\mathrm{H}-3$ to the carbonyl carbon revealed that the carbonyl group was located at C-5. This was further supported by the downfield-shifted H-3 signal in 4 with respect to that in $(1 Z, 5 S, 9 E, 11 E)$-5,9-dimethyl-12-isopropyl-6-oxocyclotetradeca-1,9,11-triene-1,5carbolactone $\left(\delta_{\mathrm{H}} 6.72\right.$ in $2 ; \delta_{\mathrm{H}} 6.07$ in $(1 Z, 5 S, 9 E, 11 E)$-5,9-dimethyl-12-isopropyl-6-oxocyclotetradeca1,9,11-triene-1,5-carbolactone). Detailed 2D NMR analyses [ ${ }^{1} \mathrm{H}-{ }^{1} \mathrm{H}$ COSY, HSQC, and HMBC (Figures S21-23)] permitted the establishment of the gross structure of 4 as depicted in Figure 2. The absolute configuration of the only chiral center C-8 in $\mathbf{4}$ was proposed as $S$ based on comparison of its specific rotation $\left([\alpha]_{\mathrm{D}}^{20}+190.8\right)$ with $(1 Z, 5 S, 9 E, 11 E)$-5,9-dimethyl-12-isopropyl-6-oxocyclotetradeca-1,9,11triene-1,5-carbolactone $\left([\alpha]_{\mathrm{D}}^{20}+177\right)$, which was also supported by the biogenetic origin of this skeleton. Interestingly, cembranoids with C-3 and C-7 cyclization exclusively give $R$ configuration at C-8 [20]. Compound 4 was given the trivial name sarcophelegan $\mathrm{D}$.

The known compounds emblide (5) [4], ketoemblide (6) [24], sarcrassin D (7) [4], sarsolilides B (8) [20], sarsolilide C (9) [20], and dihydrosarsolenone (10) [20] were identified by comparison of their NMR and MS data with those in the literature.

\subsection{Antimigratory Activity}

Metastasis is one of the major biological characteristics of cancer cells. The wound-healing assay is a simple and widely used tool to investigate in vitro directional cell migration $[5,25,26]$. The effects of compounds 1-10 on the migration of human breast cancer MDA-MB-231 cells were evaluated using wound-healing assays. The ability of the compounds to inhibit the migration of the cancer cells into the wound is measured by comparing the original wound width before assay with the wound width after $48 \mathrm{~h}$ incubation [relative wound closure $=\left(\mathrm{W}_{0}-\mathrm{W}_{48}\right) / \mathrm{W}_{0}$ ]. The higher antimigratory activity of the compound is, the smaller the wound-relative closure value it generates. 
Among 1-10, compounds 2 and $\mathbf{6}$ had the greatest capability to inhibit the migration of MDA-MB-231 cells while others did not show evident activity in comparison with control. Furthermore, compounds 2 and 6 inhibited the cell migration in a time dependent manner (Figure 5B).

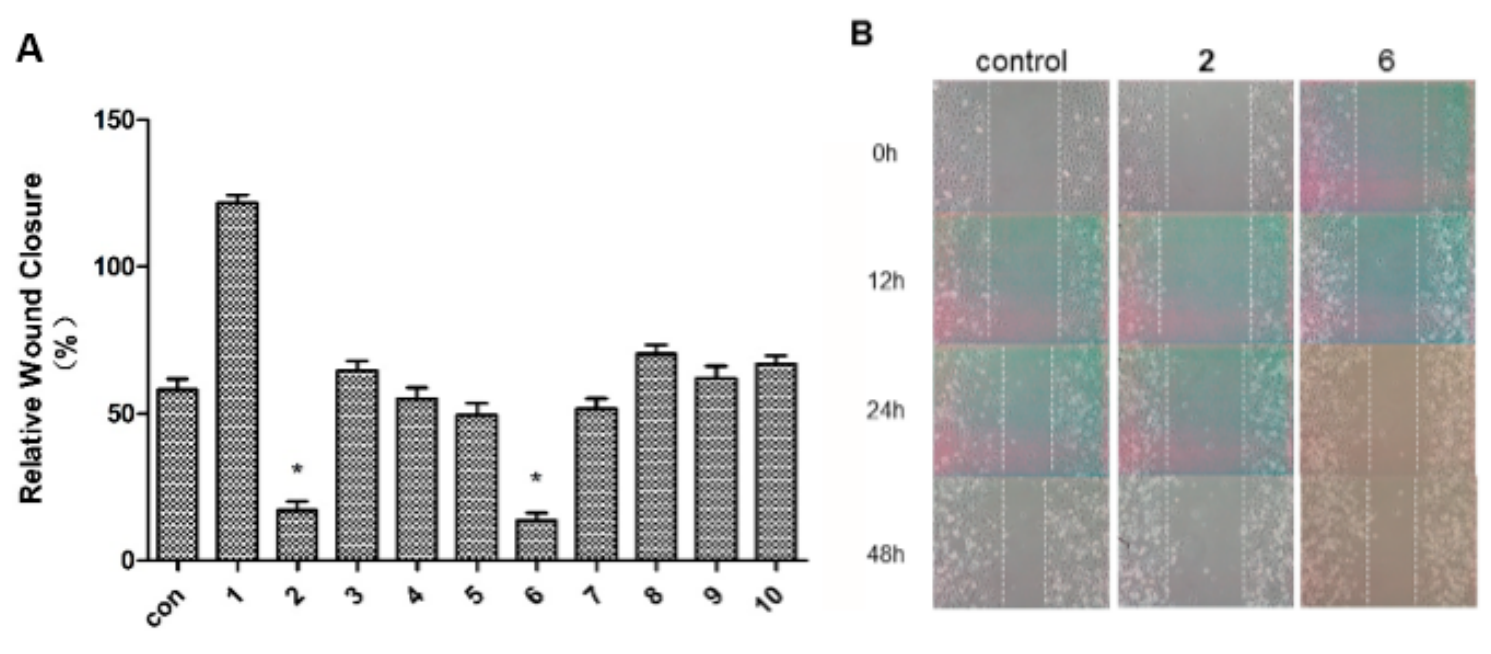

Figure 5. Wound-healing assays on compounds 1-10 with human breast tumor cell MDA-MB-231. (A) The antimigration effects of $\mathbf{1 - 1 0}$ at $10 \mu \mathrm{M}$ on the tumor cells $(* p<0.05)$;

(B) The incubation of $\mathbf{2}$ and $\mathbf{6}$ with tumor cells at $0,12,24$, and $48 \mathrm{~h}$ (left: control; middle: $\mathbf{2}$ at $10 \mu \mathrm{M}$; right: 6 at $10 \mu \mathrm{M})$.

\section{Experimental Section}

\subsection{General Experimental Procedures}

X-ray data were collected using an Agilent Xcalibur Nova X-ray diffractometer (Agilent, Santa Clara, CA, USA). Melting points were measured on an X-4 melting instrument and are uncorrected. Optical rotations were measured on a Perkin-Elmer 341 polarimeter (Perkin-Elmer, Waltham, MA, USA). UV spectra were recorded on a Shimadzu UV-2450 spectrophotometer (Shimadzu, Kyoto, Japan). IR spectra were determined on a Bruker Tensor 37 infrared spectrophotometer (Bruker, Karlsruhe, Germany). NMR spectra were measured on a Bruker AM-400 spectrometer (Bruker, Karlsruhe, Germany) at $25{ }^{\circ} \mathrm{C}$. ESIMS was measured on a Finnigan LCQ Deca instrument (Thermo Finnigan, San Jose, CA, USA), and HRESIMS was performed on a Waters Micromass Q-TOF (Waters, Milford, MA, USA). A Shimadzu LC-20 AT equipped with a SPD-M20A PDA detector (Shimadzu, Kyoto, Japan) was used for HPLC. A YMC-pack ODS-A column $(250 \times 10 \mathrm{~mm}$, S-5 $\mu \mathrm{m}, 12 \mathrm{~nm})$ (YMC, Tokyo, Japan) was used for semipreparative HPLC separation. Wound closure was monitored and photographed with a Nikon Eclipse inverted microscope. Silica gel (300-400 mesh, Qingdao Marien Chemical Co., Ltd., Qingdao, Shandong, China), reversed-phase $\mathrm{C}_{18}\left(\mathrm{Rp}-\mathrm{C}_{18}\right)$ silica gel (12 nm, S-50 $\mu \mathrm{m}$, YMC Co., Ltd., Kyoto, Japan), Sephadex LH-20 gel (Amersham Biosciences, Piscataway, NJ, USA), and MCI gel (CHP20P, 75-150 $\mu \mathrm{m}$, Mitsubishi Chemical Industries Ltd. Tokyo, Japan) were used for column chromatography (CC). All solvents used were of analytical grade (Guangzhou Chemical Reagents Co., Ltd., Guangzhou, China). 


\subsection{Animal Material}

The soft coral S. elegans were collected from the Xisha Islands in the South China Sea, in October 2014 , at a depth of 8-10 m of water. The biological material was frozen immediately until used and was identified by Cheng-Qi Fan from East China Sea Fisheries Research Institute. A voucher specimen (accession number: HLRZ201410) has been deposited at the School of Pharmaceutical Sciences, Sun Yat-sen University, Guangzhou, China.

\subsection{Extraction and Isolation}

The frozen samples $\left(1 \mathrm{~kg}\right.$, wet weight) were extracted with $\mathrm{CH}_{2} \mathrm{Cl}_{2} / \mathrm{MeOH}(1: 1,3 \times 1 \mathrm{~L})$ at room temperature. After removal of solvent in vacuo, the residue $(16 \mathrm{~g})$ was suspended in $\mathrm{H}_{2} \mathrm{O}(200 \mathrm{~mL})$ and partitioned sequentially to give dried petroleum ether $(2 \mathrm{~g})$ and EtOAc $(4 \mathrm{~g})$ extracts. The EtOAc extract was subjected to silica gel column chromatography eluted with a $\mathrm{CH}_{2} \mathrm{Cl}_{2} / \mathrm{MeOH}$ gradient $(100: 1 \rightarrow 10: 1)$ to afford five fractions (I-V). Fr. II (460 mg) was subjected to $\mathrm{Rp}-\mathrm{C}_{18}$ silica gel $\mathrm{CC}$ eluted with $\mathrm{MeOH} / \mathrm{H}_{2} \mathrm{O}$ (6:4 to 10:0), followed by a Sephadex LH-20 and eluted with EtOH to afford 2 (11 mg), 5 (72 mg), 6 (45 mg), and 7 (3.7 mg). Fr. III (1.4 g) was chromatographed over Sephadex LH-20 $\left(\mathrm{CH}_{2} \mathrm{Cl}_{2} / \mathrm{MeOH}, \mathrm{v} / \mathrm{v}, 1: 1\right)$, followed by $\mathrm{Rp}-\mathrm{C}_{18}$ silica gel eluted with a $\mathrm{CH}_{3} \mathrm{CN} / \mathrm{H}_{2} \mathrm{O}$ gradient $(5: 5 \rightarrow 10: 0)$ to obtain four sub-fractions (Fr. IIIa-IIId). Fr. IIIb was further separated by HPLC equipped with an ODS-18 column using $\mathrm{CH}_{3} \mathrm{CN} / \mathrm{H}_{2} \mathrm{O}\left(65: 35, v / v ; 3 \mathrm{~mL} \cdot \mathrm{min}^{-1}\right)$ to afford $1\left(8.1 \mathrm{mg}, t_{\mathrm{R}} 8.5 \mathrm{~min}\right), 8\left(6 \mathrm{mg}, t_{\mathrm{R}}\right.$ $11 \mathrm{~min})$, and $9\left(18 \mathrm{mg}, t_{\mathrm{R}} 13.5 \mathrm{~min}\right)$. Fr. IIId was purified by repeating the HPLC conditions described above to yield 3 (41 mg, $\left.t_{\mathrm{R}} 13 \mathrm{~min}\right)$ and 4 (3.7 mg, $\left.t_{\mathrm{R}} 17 \mathrm{~min}\right)$. Fr. IIIc was chromatographed with silica gel $\mathrm{CC}\left(\mathrm{CH}_{2} \mathrm{Cl}_{2} / \mathrm{MeOH}, 40: 1\right)$ to give $\mathbf{1 0}(25.2 \mathrm{mg})$.

\subsection{Cell Culture}

Human breast tumor cells (MDA-MB-231) were obtained from the Institute of Chinese Academy of Medical Sciences, Beijing, China. MDA-MB-231 cells were cultured in RPMI-1640 containing 10\% FBS in cell culture flasks under a humidified $5 \% \mathrm{CO}_{2}$ and $95 \%$ air atmosphere at $37{ }^{\circ} \mathrm{C}$.

\subsection{Wound-Healing Assays}

The method used to detect migration by wound-healing assay was previously described $[5,25,26]$. Briefly, the cells were allowed to grow to $90 \%$ confluence in 6-well plates. Once the monolayer was developed, a wound was made by scrapping with a $100 \mu \mathrm{L}$ pipet tip to create a denuded zone (gap) of constant width. Subsequently, cellular debris was washed with 2\%o FBS, and the MDA-MB-231 cells were exposed to $10 \mu \mathrm{M}$ of compounds 1-10. Wound closure was monitored and photographed at $0,12 \mathrm{~h}$, $24 \mathrm{~h}$, and $48 \mathrm{~h}$ with a Nikon Eclipse inverted microscope. Wound width was measured immediately before $\left(\mathrm{W}_{0}\right)$ and after the $48 \mathrm{~h}\left(\mathrm{~W}_{48}\right)$ incubation. To quantify the migrated cells, pictures of the initial wounded monolayers were compared with the corresponding pictures of cells at the end of the incubation. Artificial lines fitting the cutting edges were drawn on pictures of the original wounds and overlaid on the pictures of cultures after incubation. Figure 5A represents wound closure values for different compounds $(\mathbf{1}-\mathbf{1 0})$, relative to the control (time 0$)$. 


\subsection{Statistical Analysis}

Data were expressed as the mean $\pm \mathrm{SD}$ of at least three independent experiments. To compare three or more groups, one-way analysis of variance (ANOVA) was used followed by Newman-Keuls post hoc test. Statistical analysis was performed using GraphPad Prism software (5.01, GraphPad Software Inc., San Diego, CA, USA).

Sarcopelegan A (1): Colorless crystals; mp $187-189^{\circ} \mathrm{C} ;[\alpha]_{\mathrm{D}}^{20}+16.7(c 0.23, \mathrm{MeOH}) ; \mathrm{UV}(\mathrm{MeOH}) \lambda_{\max }$ $(\log \varepsilon) 208.4(6.82) \mathrm{nm}$; IR (KBr) $v_{\max } 3451,2958,2925,1716,1237 \mathrm{~cm}^{-1}$; ${ }^{1} \mathrm{H}$ - and ${ }^{13} \mathrm{C}-\mathrm{NMR}$ data see Tables 1 and 2; HRESIMS $m / z 333.2059$ (calcd for $\mathrm{C}_{20} \mathrm{H}_{29} \mathrm{O}_{4}\left[\mathrm{M}-\mathrm{H}_{2} \mathrm{O}+\mathrm{H}\right]^{+}, 333.2066$ ).

Sarcopelegan B (2): Colorless oil; $[\alpha]_{\mathrm{D}}^{20}-3.7$ (c 0.46, MeOH); UV (MeOH) $\lambda_{\max }(\log \varepsilon) 230.4$ (6.82) nm; IR (KBr) $v_{\max } 3396,2933,1699,1381,983 \mathrm{~cm}^{-1}$; ${ }^{1} \mathrm{H}$ - and ${ }^{13} \mathrm{C}-\mathrm{NMR}$ data see Tables 1 and 2; HRESIMS $m / z 373.1986$ (calcd for $\mathrm{C}_{20} \mathrm{H}_{30} \mathrm{O}_{5} \mathrm{Na}[\mathrm{M}+\mathrm{Na}]^{+}, 373.1991$ ).

Sarcopelegan C (3): Colorless oil; $[\alpha]_{\mathrm{D}}^{20}-10.0$ ( c 0.14, MeOH); UV (MeOH) $\lambda_{\max }(\log \varepsilon) 232.2$ (7.17), $210.0(7.05) \mathrm{nm}$; IR (KBr) $v_{\max } 3357,2966,2929,1694,1071 \mathrm{~cm}^{-1} ;{ }^{1} \mathrm{H}-$ and ${ }^{13} \mathrm{C}-\mathrm{NMR}$ data see Tables 1 and 2; HRESIMS $m / z 375.2147$ (calcd for $\mathrm{C}_{20} \mathrm{H}_{32} \mathrm{O} 5 \mathrm{Na}[\mathrm{M}+\mathrm{Na}]^{+}, 375.2143$ ).

Sarcopelegan D (4): Colorless oil; $[\alpha]_{\mathrm{D}}^{20}+190.8$ (c 0.20, MeOH); UV (MeOH) $\lambda_{\max }(\log \varepsilon) 298.2$ (7.10), $219.8(6.98) \mathrm{nm}$; IR (KBr) $v_{\max } 3454,2961,2067,1621,1270 \mathrm{~cm}^{-1} ;{ }^{1} \mathrm{H}-$ and ${ }^{13} \mathrm{C}-\mathrm{NMR}$ data see Tables 1 and 2; HRESIMS $m / z 331.1901$ (calcd for $\mathrm{C}_{20} \mathrm{H}_{27} \mathrm{O}_{4}[\mathrm{M}+\mathrm{H}]^{+}, 331.1909$ ).

Crystal data for compound (1): $\mathrm{C}_{20} \mathrm{H}_{30} \mathrm{O}_{5}, \mathrm{M}=350.44,0.5 \times 0.1 \times 0.2 \mathrm{~mm}^{3}$, space group P65 (No. 170), $V=2769.03(4) \AA^{3}, Z=6, D_{\mathrm{c}}=1.261 \mathrm{~g} \cdot \mathrm{cm}^{-3}, F_{000}=1140$, Xcalibur, Onyx, Nova, Cu Ka radiation, $\lambda=1.54184 \AA, T=293(2) \mathrm{K}, 2 \theta_{\max }=143.5^{\circ}, 35758$ reflections collected, 3601 unique $\left(\mathrm{R}_{\text {int }}=0.0507\right)$. Final $G o o F=1.043, R_{1}=0.0285, w R_{2}=0.0757, R$ indices based on 3523 reflections with $\mathrm{I}>2$ sigma (I) (refinement on $F^{2}$ ), 232 parameters, 1 restraint. Lp and absorption corrections applied, $\mu=0.723 \mathrm{~mm}^{-1}$. Flack parameter $=-0.02$ (11). Crystallographic data for the structure of 1 have been deposited in the Cambridge Crystallographic Data Centre (deposition number: CCDC 1401385). The data can be obtained free of charge via http://www.ccdc.cam.ac.uk/conts/retrieving.html (or from the CCDC, 12 Union Road, Cambridge CB2 1EZ, UK; Fax: +44 1223 336033; E-mail: deposit@ccdc.cam.ac.uk).

\section{Conclusions}

Four new cembranoids and six known analogues were isolated from the South China Sea soft coral S. elegans, collected from the Xisha Islands. Their structures were elucidated through detailed spectroscopic analysis, and the absolute configuration of 1 was confirmed by single-crystal X-ray diffraction. The antimigratory potential of compounds $\mathbf{1}-\mathbf{1 0}$ were evaluated, two of which were found to inhibit human breast tumor MDA-MB-231 cell migration at $10 \mu \mathrm{M}$. The current research not only expanded the members of the cembranoid family, but may also provide some diterpene prototypes for further development of anti-cancer leads with antimigratory properties. 


\section{Supplementary Materials}

1D and 2D NMR spectra of $\mathbf{1} \mathbf{- 4}$ were provided. These materials can be accessed at: http://www. mdpi.com/1420-3049/20/07/13324/s1.

\section{Acknowledgments}

The authors thank the Science and Technology Planning Project of Guangdong Province (No. 2013B021100009), the Guangdong Natural Science Funds for Distinguished Young Scholars (No. 2014A030306047), and the National High Technology Research and Development Program of China (863 Projects, No. 2015AA020928) for providing financial support to this work.

\section{Author Contributions}

S.Y. designed the research; X.L., J.Z. and Q.L. performed the experimental work; X.L., G.T., H.W., and C.F. wrote the manuscript. All authors discussed, edited and approved the final version.

\section{Conflicts of Interest}

The authors declare no conflict of interest.

\section{References}

1. Li, Y.; Peng, L.; Zhang, T. Progress of studies on the natural cembranoids from the soft coral species of Sarcophyton genus. Med. Chem. Bioact. Nat. Prod. 2006, 19, 257-300.

2. Gross, H.; Konig, G.M. Terpenoids from marine organisms: Unique structures and their pharmacological potential. Phytochem. Rev. 2006, 5, 115-141.

3. Jia, R.; Guo, Y.W.; Chen, P.; Yang, Y.M.; Mollo, E.; Gavagnin, M.; Cimino, G. Biscembranoids and their probable biogenetic precursor from the Hainan soft coral Sarcophyton tortuosum. J. Nat. Prod. 2007, 70, 1158-1166.

4. Zhang, C.X.; Li, J.; Su, J.Y.; Liang, Y.J.; Yang, X.P.; Zheng, K.C.; Zeng, L.M. Cytotoxic diterpenoids from the soft coral Sarcophyton crassocaule. J. Nat. Prod. 2006, 69, 1476-1480.

5. Sawant, S.S.; Youssef, D.T.A.; Reiland, J.; Ferniz, M.; Marchetti, D.; El Sayed, K.A. Biocatalytic and antimetastatic studies of the marine cembranoids sarcophine and 2-epi-16-deoxysarcophine. J. Nat. Prod. 2006, 69, 1010-1013.

6. Gross, H.; Wright, A.D.; Beil, W.; Konig, G.M. Two new bicyclic cembranolides from a new Sarcophyton species and determination of the absolute configuration of sarcoglaucol-16-one. Org. Biomol. Chem. 2004, 2, 1133-1138.

7. Kim, H.; Lee, H.; Kim, J.; Kim, S.; Kim, D. A general strategy for synthesis of both (6Z)- and (6E)cladiellin diterpenes: Total syntheses of (-)-cladiella-6,11-dien-3-ol, (+)-polyanthellin A, (-)-cladiell11-ene-3,6,7-triol, and (-)-deacetoxyalcyonin acetate. J. Am. Chem. Soc. 2006, 128, 15851-15855.

8. Crimmins, M.T.; Stauffer, C.S.; Mans, M.C. Total syntheses of (+)-vigulariol and (-)-sclerophytin A. Org. Lett. 2011, 13, 4890-4893. 
9. Bie, W.; Deng, Z.W.; Xu, M.J.; Lin, W.H. Structural elucidation of a new cembranoid diterpene from the Chinese soft coral Sarcophyton sp. J. Chin. Pharm. Sci. 2008, 17, 221-224.

10. Xi, Z.; Bie, W.; Chen, W.; Liu, D.; Leen, V.O.; Proksch, P.; Lin, W. Sarcophytolides G-L, new biscembranoids from the soft coral Sarcophyton elegans. Helv. Chim. Acta 2013, 96, 2218-2227.

11. Xi, Z.; Bie, W.; Chen, W.; Liu, D.; Leen, V.O.; Proksch, P.; Lin, W. Sarcophyolides B-E, new cembranoids from the soft coral Sarcophyton elegans. Mar. Drugs 2013, 11, 3186-3196.

12. Minh, C.V.; Kiem, P.V.; Nguyen, H.N.; Nguyen, X.C.; Nguyen, P.T.; Nguyen, H.D.; Quang, T.H.; Nguyen, T.D.; Thung, D.C.; Thuy, D.T.T. Carotenoids from the soft coral Sarcophyton elegans. Tap Chi Hoa Hoc. 2010, 48, 627-631.

13. Bishara, A.; Rudi, A.; Benayahu, Y.; Kashman, Y. Three biscembranoids and their monomeric counterpart cembranoid, a biogenetic Diels-Alder precursor, from the soft coral Sarcophyton elegans. J. Nat. Prod. 2007, 70, 1951-1954.

14. Anjaneyulu, A.S.R.; Gowri, P.M.; Venugopal, M.J.R.V.; Sarada, P.; Murthy, M.V.R.K.; Rao, G.V.; Murthy, P.S.N.; Rao, C.V.; Kumar, G. Novel diterpenoids from the Indian Ocean soft coral Sarcophyton elegans. J. Ind. Chem. Soc. 1999, 76, 656-659.

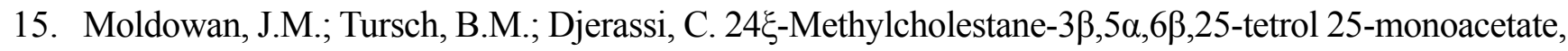
a novel polyhydroxylated steroid from an alcyonarian. Steroids 1974, 24, 387-398.

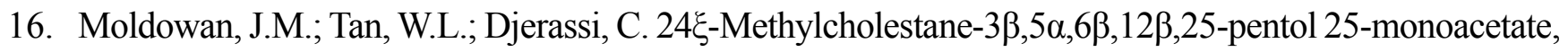
a novel polyoxygenated marine sterol. Steroids 1975, 26, 107-128.

17. Cheng, Z.B.; Deng, Y.L.; Fan, C.Q.; Han, Q.H.; Lin, S.L.; Tang, G.H.; Luo, H.B.; Yin, S. Prostaglandin derivatives: nonaromatic phosphodiesterase-4 inhibitors from the soft coral Sarcophyton ehrenbergi. J. Nat. Prod. 2014, 77, 1928-1936.

18. Sun, Z.H.; Cai, Y.H.; Fan, C.Q.; Tang, G.H.; Luo, H.B.; Yin, S. Six new tetraprenylated alkaloids from the South China Sea Gorgonian Echinogorgia pseudossapo. Mar. Drugs 2014, 12, 672-681.

19. Cheng, Z.B.; Xiao, H.; Fan, C.Q.; Lu, Y.N.; Zhang, G.; Yin, S. Bioactive polyhydroxylated sterols from the marine sponge Haliclona crassiloba. Steroids 2013, 78, 1353-1358.

20. Liang, L.F.; Kurtan, T.; Mandi, A.; Gao, L.X.; Li, J.; Zhang, W.; Guo, Y.W. Sarsolenane and capnosane diterpenes from the Hainan soft coral Sarcophyton trocheliophorum Marenzeller as PTP1B Iinhibitors. Eur. J. Org. Chem. 2014, 2014, 1841-1847.

21. Liang, L.F.; Lan, L.F.; Orazio, T.S.; Guo, Y.W. Sartrolides A-G and bissartrolide, new cembranolides from the South China Sea soft coral Sarcophyton trocheliophorum Marenzeller. Tetrahedron 2013, 69, 7381-7386.

22. Zou, G.A.; Ding, G.; Su, Z.H.; Yang, J.S.; Zhang, H.W.; Peng, C.Z.; Aisa, H.A.; Zou, Z.M. Lactonecembranoids from Croton laevigatus. J. Nat. Prod. 2010, 73, 792-795.

23. Bowden, B.F.; Coll, J.C.; Willis, R.H. Studies of Australian soft corals. XXVII. Two novel diterpenes from Sarcophyton glaucum. Aust. J. Chem. 1982, 35, 621-627.

24. Uchio, Y.; Nitta, M.; Nakayama, M.; Iwagawa, T.; Hase, T. Ketoemblide and sarcophytolide, two new cembranolides with $\varepsilon$-lactone function from the soft coral Sarcophyta elagans. Chem. Lett. 1983, 4 , 613-616. 
25. Huang, G.J.; Yang, C.M.; Chang, Y.S.; Amagaya, S.; Wang, H.C.; Hou, W.C.; Huang, S.S.; Hu, M.L. Hispolon suppresses SK-Hep1 human hepatoma cell metastasis by inhibiting matrix metalloproteinase-2/9 and urokinase-plasminogen activator through the PI3K/Akt and ERK signaling pathways. J. Agric. Food Chem. 2010, 58, 9468-9475.

26. Lu, W.Q.; Liu, X.F.; Cao, X.W.; Xue, M.Z.; Liu, K.D.; Zhao, Z.J.; Shen, X.; Jiang, H.L.; Xu, Y.F.; Huang, J.; et al. Shafts: A hybrid approach for 3D molecular similarity calculation. 2. Prospective case study in the discovery of diverse p90 ribosomal S6 protein kinase 2 inhibitors to suppress cell migration. J. Med. Chem. 2011, 54, 3564-3574.

Sample Availability: Samples of the compounds 1-10 are available from the authors.

(C) 2015 by the authors; licensee MDPI, Basel, Switzerland. This article is an open access article distributed under the terms and conditions of the Creative Commons Attribution license (http://creativecommons.org/licenses/by/4.0/). 